\title{
Transforming Growth Factor Beta 1 (TGFß1) as an Immunological Marker in Breast Cancer Patients
}

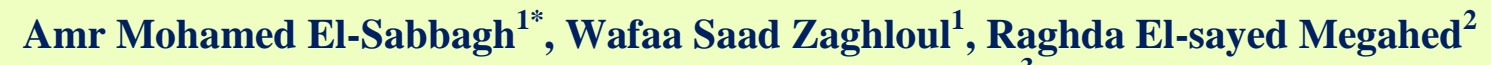 \\ and Nazem Mohammed Shams ${ }^{3}$ \\ ${ }^{I}$ Department of Medical Microbiology and Immunology, Faculty of Medicine, \\ Mansoura University, Egypt \\ ${ }^{2}$ Mansoura Fever Hospital, Ministry of Health, ${ }^{3}$ Department of general surgery, Faculty of \\ Medicine, Mansoura University, Egypt \\ *Corresponding author
}

\section{A B S T R A C T}

Breast cancer is one of the most public and fatal malignancy worldwide. One of the main cytokines playing a role in breast cancer progression is TGF $\beta 1$. In this

\section{Keywords}

Fatal malignancy,

Cytokines, TGF $\beta 1$

Predictors

Article Info

Accepted:

12 March 2020

Available Online:

10 April 2020 study we aimed to determine the clinical significance of the serum TGF $\beta 1$ levels in breast cancer patients by comparing the levels of TGF $\beta 1$ in breast cancer patients and in control females, assessment of the levels of TGF $\beta 1$ in diagnosed breast cancer patients before and after treatment and correlating between the levels of TGF $\beta 1$ in breast cancer patients with the laboratory and radiological findings. Our study was carried out on 35 breast cancer female cases and 20 females free from breast cancer with matched age as a control group. Higher levels of TGF $\beta 1$ are detected among breast cancer females than the control group with statistically significant difference between TGF $\beta 1$ after treatment as regarding to metastasis occurrence. This indicates that the circulating TGF $\beta 1$ after treatment may be used as a prognostic marker in breast cancer patients. Also, our study shows that there were statistically significant predictors affecting metastasis rate among studied cases when both ER was positive and TGF $\beta 1$ after treatment was more than median.

\section{Introduction}

Breast cancer (BC) is the most public and deadly malignancy worldwide, with high morbidity and mortality in women (Gomes et al., 2012). Worldwide, there will be about 2.1 million newly diagnosed female breast cancer cases in 2018, accounting for almost 1 in 4 cancer cases among women. The disease is the greatest regularly identified cancer in most of countries (Bray et al., 2018).

Numerous issues are involved in the mechanism of breast cancer, including 
biological, genetic and environmental factors (Porter, 2009). One of the biological factors is cytokines, which play an important role in inflection of cellular growing, differentiation, and cancer evolution. Transforming growth factor $\beta$ eta (TGF $\beta$ ), is one of the important cytokines playing an important role in the induction of cellular growing, differentiation, and cancer evolution (Sheen et al., 2013).

The TGF $\beta$ is a polypeptide 112 amino acid (AA), encoded by a gene located on the long arm of chromosome 19 (19 q13) in humans (Amani et al., 2014). TGF $\beta$ occurs in five isomeric forms (60-80\% of homology), from $\beta 1$ to $\beta 5$, produced by alternative splicing (Kajdaniuk et al., 2013).

The role of TGF $\beta 1$ in cancer development and its growing depend on many factors especially the tumor type and stage. This cytokine acts as a potent growth inhibitor. It has been shown that the TGF $\beta 1$ promote apoptosis and inhibit epithelial cell cycle progression, which are responsible for the suppressive role during cancer beginning and progression (Parvani et al., 2013).

TGF $\beta 1$ have the ability to encourage and help epithelial to mesenchymal transition (EMT), which increase tumor cell motility and spread (Massagué, 2012). So, TGF $\beta 1$ is regarded as a metastasis inducer, playing a role in tumour development, progression and angiogenesis (Darakhshan and Ghanbari, 2013). These opposing, dichotomous TGF $\beta 1$ actions in cancer growth and advance are known as "TGF $\beta 1$ paradox" (Parvani et al., 2011).

The TGF $\beta 1$ creates angiogenesis, microenvironment suitable to tumor growth; increasing the attraction between cancer cells and the cell adhesion molecules, and increasing cancer cells invasiveness and metastasis. Furthermore, TGF $\beta 1$ stimulates death of the surrounding healthy cells, helping the tumour spread (Kajdaniuk et al., 2013).

At the advanced stages of tumour progression, TGF $\beta 1$ is shifting its action into tumor supporter. Several studies have revealed a probable role of TGF $\beta 1$ on cancer metastasis (Panis et al., 2013).

The studies recommend that TGF $\beta 1$ could inhibit the primary cancer growth while stimulating metastasis through its EMT action. In a certain study, a decrease in tumor recurrence was noticed with complete inhibition of TGF $\beta 1$ response. Also, an increase in pulmonary metastasis was also occurred with increased TGF $\beta 1$ (Bierie et al., 2008).

Moreover, it has been reported that TGF $\beta 1$ stimulation inhibits natural killer (NK) cell and neutrophil effectors roles, which is responsible tumor spread in a suitable environment. Also, TGF $\beta 1$ has been shown to inhibit major histocompatibility complex (MHC I and MHC II) expression in many human cells. Notably, the TGF $\beta 1$ inhibition of MHC I expression in tumor cells results in decreased tumor cell lyses by NK cells, which help tumor growing and metastasis (Lee et al., 2004).

The TGF $\beta 1$ is one of the greatest chemoattractants for human neutrophils that also inhibits their ability to overwhelm cancer beginning and effectively controls the interaction between the human neutrophils and other types of cells within the tumor environment. Neutrophils plays an important role in is the recognition and destruction of tumour cells. In the presence of TGF $\beta 1$, neutrophils show a decreased ability to destruct tumour cells. TGF $\beta 1$ also helping recruitment of monocytes and play a role in the differentiation of monocyte to macrophage. TGF $\beta 1$ inhibits killing of tumor 
cells by macrophages by blocking interferon$\alpha$ stimulation and lipopolysaccharide (LPS) triggering of macrophages. So, TGF $\beta 1$ injection attenuates the cytotoxicity activity of macrophages towards the tumour cells in vitro (Bierie et al., 2008).

The aim of this study is to determine the clinical significance of the serum TGF $\beta 1$ levels in breast cancer patients by comparing the levels of TGF $\beta 1$ in breast cancer patients and in control females, assessment of the levels of TGF $\beta 1$ in diagnosed breast cancer patients who did not receive any treatment and after treatment and correlating between the levels of TGF $\beta 1$ in breast cancer patients with the laboratory and radiological findings.

\section{Materials and Methods}

\section{Subjects}

The present case control study was carried out on 35 female patients with breast cancer at various stages, admitted to the Oncology Center, Mansoura University. The study was done over a period of 15 months from December 2015 to February 2017.

Out of these 35 patients, 19 cases were in stage II, 16 cases were in stage III.

The mean age of patients was 50.09 years (SD \pm 11.77 ), and their ages ranged between 29 and 70 years.

Patients underwent to full examination including; name, age, marital status, menstrual and reproductive history.

The present study cases were diagnosed on the Oncology Center on the basis of:

-Radiological examination including; mammogram, breast US, Pelvic US, Pre and post contrast CT neck, chest and abdomen (according the case needs).
-Laboratory investigations including; LDH level, CA15-3 level, (ER) and progesterone receptor (PR) levels by an Allred scoring system which is based on the percentage of cells that stain by immune histochemistry for ER and PR (on a scale of 0 to5) and the intensity of that staining (on a scale of 0 to 3 ) for a possible total score of 8 (Segen's Medical Dictionary, 2012).

-Pathological examination including; gross appearance, microscopic examination and diagnosis.

-Clinical staging for different types of cancer.

-The stage of the cancer is primarily determined clinically. Doctors may refer stage I to stage IIA cancer as early stage, and stage IIB to stage III as locally advanced and stage IV as metastatic one (Cancer. Net Editorial Board, 2019).

Metastasis was assessed in patients and follow up during the time of treatment.

The level of TGF $\beta 1$ was assessed in our patients twice, before the start of any type of therapy and after therapy.

Patients received different types of therapy. Out of 35 breast cancer patients; 14 cases underwent surgery, 32 cases received chemotherapy for about 6 months, 14 cases received post-operative radiotherapy (PORT) about 15 sessions for 3 months, and 20 cases received hormonal therapy for about one year.

This study included also 20 control females with matched age. They were selected from nurses and medical staff at Mansoura Oncology Center. Control group cases were subjected to laboratory and radiological investigations. All of them were proved to be completely free from breast cancer. 


\section{Sample collection}

Two blood samples were taken by venipuncture from every breast cancer patient. The first blood sample was taken at the start of therapy and the second was taken after 9 months from starting chemotherapy and after one year from starting hormonal therapy.

Five $\mathrm{mL}$ of blood were taken under complete aseptic precautions. Samples were transported to the Immunology unit, Medical Microbiology and Immunology Department, Mansoura Faculty of Medicine. Samples were centrifuged at $1000 \mathrm{rpm}$ for 15 minutes and the separated serum were collected and stored at $-20^{\circ} \mathrm{c}$ until TGF $\beta 1$ measurement by ELISA procedure.

From each control female, another blood sample was taken and processed and evaluated by the same patient's method.

\section{Methods}

Determination of the serum level of TGF $\beta 1$ by ELISA (Kono Biotech Co., Ltd, Singapora, China)

\section{Statistical analysis}

Data were statistically analyzed using the statistical package for social sciences (SPSS) version 22 .

Qualitative data were described as numbers and percentages with Chi Square $\left(\mathrm{X}^{2}\right)$ test used for comparison

Qualitative data were described as median and range after testing normality by Kolmogorove-Smirnov test. For comparison between groups, Mann-Whitney tests and Kruskal-Wallis test were used. To calculate validity, receiver operating characteristics
(ROC) were used for continuous variables with calculation of best cut off point. For nonparametric correlation between continuous variables, spearman correlation coefficient (r) was used.

Level of significance: (p-value).

The results were considered:

-Non-significant

Occur if the probability of error is more than $5 \%$.

-Significant

Occur if the probability of error is less than $5 \%$.

-Highly Significant

Occur if the probability of error is less than $0.1 \%$.

Quantitative data between two groups:

1) Parametric tests:

T-test was used to relate 2 independent groups.

2) Non Parametric tests:

Mann-Whitney $U$ test was used to relate 2 independent groups.

3) Spearman's correlation.

4) Kaplan-Meier test.

5) Cox regression.

\section{Results and Discussion}

Thirty five women (35) women with breast cancer and 20 control women were included in our study. The 35 breast cancer women were at various stages, admitted to the Oncology Center, Mansoura University and diagnosed as breast cancer by clinical, laboratory and radiological evidences while, the 20 control women were diagnosed free from breast cancer by negative laboratory and radiological findings.

Table-1 shows no significant difference between breast cancer females and control 
group females as regarding age, marital status and number of children.

Also, our results shows higher number of female in menopause among breast cancer cases 26 versus 6 in the control group.

Among the breast cancer females; 19 female which represent $54.3 \%$ of breast cancer cases were stage II and 16 female which represent $45.7 \%$ were stage III.

Our result shows the median number of ER in breast cancer females was 7 and PR were 6 according to Allred score test from (0-8). Median number of LDH was $349.66 \mathrm{U} / \mathrm{l}$ and median number of CA 15-3 was $40 \mathrm{U} / \mathrm{ml}$.

NB: The reference range for CA15-3 (0-25) $\mathrm{U} / \mathrm{ml}$ and for LDH is (140-280) U/l (BT 3500, Roma, Italy)

Also our results show statistically significant difference ( $\mathrm{P}$ value: 0.029) with higher TGF $\beta 1$ before treatment among breast cancer cases $160.9 \mathrm{ng} / \mathrm{l}$ versus 127.85ng/l in the control group. Also, statically significant difference was found between TGF $\beta 1$ before and after treatment in breast cancer females with median $160.9 \mathrm{ng} / \mathrm{l}$ before treatment versus $182.5 \mathrm{ng} / \mathrm{l}$ after treatment $\quad(\mathrm{P}$ value $=$ 0.047).

The table-2 shows statistically significant difference between TGF $\beta 1$ before and after treatment regarding stage III with higher median number after treatment which was 195ng/l versus $147.95 \mathrm{ng} / \mathrm{l}$ before treatment. While in stage II there is no significant difference between TGF $\beta 1$ before and after treatment. Also, it shows statistically significant difference between TGF $\beta 1$ before treatment between stage II and stage III with higher median number in stage II which was $173.6 \mathrm{ng} / \mathrm{l}$ versus $147.95 \mathrm{ng} / \mathrm{l}$ in stage III.
Table-3 shows only statistically significant inverse relationship between TGF $\beta 1$ before treatment and PR as when the TGF $\beta 1$ increased, the PR level was decreased.

Our results shows no statistically significant difference ( $\mathrm{P}$ value: 0.22) between TGF $\beta 1$ before treatment as regarding to metastasis while there is statistically significant difference between TGF $\beta 1$ after treatment as regarding metastasis, with higher metastasis among cases when TGF $\beta 1$ higher than median which was $182.5 \mathrm{ng} / \mathrm{l}$. (P value: 0.03 ) and that there is no statistically significant difference between CA15-3 as regarding to metastasis rate ( $\mathrm{P}$ value: 0.33 ).

Cox regression in table-4 shows that there were statistically significant predictors affecting free survival among studied cases when both ER was positive and TGF $\beta 1$ after treatment was more than median value.

Our results shows that every increase in TGF $\beta 1$ before treatment one unit decrease breast cancer metastasis (OR: 0.98, 95\% CI: $0.94-0.99)$.

\section{Discussion}

Breast cancer is one of the most frequent tumor diseases in women. It is clinically and molecularly complex disease driven by aberrant immunological and molecular factors.

With the development of advanced techniques for breast cancer therapy, reliable methods to evaluate the extent and type of immunological and molecular involvement present in tumors and investigation of its effect on patient prognosis and treatment are needed (Panjarian et al., 2019).

Out of 35 breast cancer women, 9 (25.7\%) were progressed to metastasis. 
In this study there was significant difference between cases of breast cancer and control group females regarding the presence of menopause with higher number of female in menopause among breast cancer cases 26 versus 6 in control group females with significant $\mathrm{p}$ value $=0.001$.

Our study showed that women at the menopause are at higher risk for breast cancer than others which was explained by the high density of parenchyma and hormonal affection. In consistent with our results, previous studies reported that females at menopause were at risk for the development of breast cancer (Anderson et al., 2014).

Also, Surakasula et al., (2014) agrees with our study, who reported that the incidence of breast cancer was found higher in postmenopausal women than premenopausal women.

In our study, out of $54.3 \%$ of breast cancer cases were stage II and $45.7 \%$ were stage III. Most of breast cancer patients have been diagnosed by grade II which reflect the ability of early detection of breast cancer.

In our study about 30 cases of breast cancer were positive for ER $(85.7 \%)$ and 29 were positive for PR (82.9\%).

Previous study by Kuroda et al., 2019 showed similar positivity for receptors. Similar observation was also made by Shushan et al., (2013).

In this study the median value of LDH was $349.66 \mathrm{U} / 1$ among breast cancer patients before treatment, as Jurisic et al., (2015) that conclude that patients with breast cancer were having higher serum LDH levels.

In our study we found the median value of CA $15-3$ value was $40 \mathrm{U} / \mathrm{ml}$ among breast cancer patients which mean that CA 15-3 increases in breast cancer patients.

Ebeling et al., (2002) agrees with our study and found that median CA 15-3 value was $17.3 \mathrm{U} / \mathrm{ml}$ in breast cancer women which is higher than control women which was 13.6 $\mathrm{U} / \mathrm{ml}$.

Our study found that elevated levels of TGF $\beta 1$ among breast cancer patients once diagnosed with significant difference from the control group. Median TGF $\beta 1$ at the time of the diagnosis (160.9 ng/l) were significantly higher in patients with breast cancer than in control group (127.85 ng/l) with $\mathrm{P}$ value $=0.029$.

TGF $\beta 1$ has been proved to be elevated among breast cancer females than control female in other studies (Teama et al., 2016).

In the present study we found TGF $\beta 1$ higher in breast cancer cases with statistically significant $\mathrm{P}$ value $=0.047$ with higher median TGF $\beta 1$ after treatment (182.5 ng/10 versus (160.9 ng/l) before treatment.

Hachim et al., (2018) agrees with our study and reported that the median TGF $\beta 1$ in breast cancer patients expressed $684 \mathrm{ng} / \mathrm{l}$ after treatment versus $121 \mathrm{ng} / \mathrm{l}$ before treatment with significant $\mathrm{P}$ value $=0.005$.

Wakefield et al., (1995) reported unchanged plasma TGF $\beta 1$ levels in advanced breast cancer patients both before and after therapy. This discrepancy could be explained by differing assay specificities and sensitivities, differing plasma preparation protocols and/or by differing patient populations.

Also, our study found higher median number of TGF $\beta 1$ after treatment regarding stage III which was 195ng/l versus147.95 ng/l before treatment with statistically significant $\mathrm{P}$ value 
$=0.002$. While, in stage II there is no significant difference between TGF $\beta 1$ before and after treatment.

Panis et al., 2012 agree with our study and reported that plasma level of TGF $\beta 1$ after treatment in stage III patients were elevated when compared with their level before treatment with significant $P$ value : 0.0442 .

Our study shows statistically significant difference between TGF $\beta 1$ before treatment between stage II and stage III with higher median number in stage II which was 173.6 $\mathrm{ng} / \mathrm{l}$ versus $147.95 \mathrm{ng} / \mathrm{l}$ in stage III.

In contrast to our findings Ivanović et al., 2006 reported that the median number of TGF $\beta 1$ in stage III was $230 \mathrm{ng} / \mathrm{l}$ and in stage II it was $89 \mathrm{ng} / \mathrm{l}$.

The present study could not explain the difference between our results that shows high median number of TGF $\beta 1$ in stage II than stage III and other studies that shows high median number of TGF $\beta 1$ in stage III than stage II, and this point needs further researches.

This study showed no statistically significant relationship between TGF $\beta 1$ before treatment and ER while there was statistically significant inverse relationship between TGF $\beta 1$ before treatment and PR as when the TGF $\beta 1$ increased; the PR level was decreased as proved by (Zarzynska, 2014).

In contrast to our findings El Aziz et al., 2018 reported that there was no significant relation between serum TGF $\beta 1$ level and hormonal status for both ER and PR.

This study found no significant relation between TGF $\beta 1$ before and after treatment and CA15-3 and LDH. In contrast to our result Sandri et al., 2012 reported a significant relation for CA15-3 and TGF $\beta 1$ as high level of TGF $\beta 1$ were associated with high CA15-3 and associated with advanced stages of cancer breast.

The cooperation between TGF $\beta 1$ and CA15-3 may occur through several possible mechanisms as activation of the Smadindependent signaling pathway or by inhibition of TGF $\beta 1$ induced anti-proliferative effects through the up regulation of the inhibitory Smad-7(Tripsianis et al., 2013).

The difference between our results and the other studies could be explained by different stages of breast cancer at the time of measuring CA15-3, our study measured CA15-3 in early stages while others measured CA15-3 in late stages.

One of the aims of this study was to establish the prognostic utility of TGF $\beta 1$ in breast cancer patients. TGF $\beta 1$ is a multifunctional cytokine with a biphasic role in breast tumor genesis, acting as tumor suppressors at early stages while stimulating tumor progression at later stages (TGF $\beta$ switch) (Dave et al., 2012).

TGF $\beta 1$ was measured before and after treatment, and then compared regarding metastasis rate; it was found that no statistically significant difference between TGF $\beta 1$ before treatment as regarding to the metastasis rate but we found statistically significant difference between TGF $\beta 1$ after treatment as regarding to the metastasis rate with $\mathrm{p}$ value $=0.03$ with higher metastasis rate among cases when TGF $\beta 1$ higher than the median which was $182.5 \mathrm{ng} / \mathrm{l}$.

In consistence with us, Ciftci et al., (2014) reported that the metastasis rate for patients with high mean and low mean serum TGF $\beta 1$ levels after treatment were $97 \%$ vs. $67 \%$, respectively with $P$ value $=0.01$. 
Scherer et al., 2016 reported that high TGF $\beta 1$ levels in breast cancer patients after treatment are sufficient to induce fibrosis and improving lymphatic drainage.

Also in our study we found no significance of CA 15-3 as regarding metastasis rate among cancer breast patients. In contrast to our finding, Mudduwa et al., 2018 concluded that elevated CA 15-3 is a predictor of short disease free survival of patients. Also, since the half-life of CA15-3 is unknown, it remains controversial how to define the optimal interval for tumor marker follow-up (Chu and Ryu, 2016). However several studies found that continuous CA15-3 elevation usually occurred in patients with disease progression (Darwish et al., 2012).

In our study Cox regression shows that there were statistically significant predictors affecting metastasis rate among studied cases when both ER was positive and TGF $\beta 1$ after treatment was more than median (Fig. 1).

Table.1 Background characteristics of both breast cancer females and control group

\begin{tabular}{|c|c|c|c|}
\hline Group & $\begin{array}{c}\text { Breast Cancer } \\
\text { cases } n=35\end{array}$ & $\begin{array}{l}\text { Control group } \\
\text { females } n=20\end{array}$ & Significance \\
\hline $\begin{array}{l}\text { Age (years) } \\
\text { mean } \pm \text { SD } \\
\text { Range }\end{array}$ & $\begin{array}{c}50.09 \pm 11.77 \\
(29-70)\end{array}$ & $\begin{array}{c}45.55 \pm 10.86 \\
(25-63)\end{array}$ & $\begin{array}{c}\mathrm{t}=1.41 \\
\mathrm{p}=0.163\end{array}$ \\
\hline $\begin{array}{l}\text { Married } \\
\text { N (\%) }\end{array}$ & 33 (94.3) & $17(85.0)$ & $\begin{array}{l}\chi^{2}=1.33 \\
P=0.25\end{array}$ \\
\hline $\begin{array}{l}\text { Number of child } \\
\leq \mathbf{3} \\
>\mathbf{3}\end{array}$ & $\begin{array}{l}15(42.9 \%) \\
20(57.1 \%)\end{array}$ & $\begin{array}{c}13(65 \%) \\
7(35 \%)\end{array}$ & $\begin{array}{l}\chi^{2}=2.49 \\
P=0.11\end{array}$ \\
\hline $\begin{array}{l}\text { Metastasis } \\
\mathbf{N}(\%)\end{array}$ & $9(25.7)$ & 0 & - \\
\hline
\end{tabular}

Table. 2 Comparison between TGF $\beta 1$ in cancer females before and after treatment regarding the clinical stages

\begin{tabular}{|c|c|c|c|c|}
\hline Stage & & $\begin{array}{c}\text { TGFß1 before } \\
\text { treatment }\end{array}$ & $\begin{array}{c}\text { TGFß1 after } \\
\text { treatment }\end{array}$ & $\begin{array}{c}\text { Significant } \\
\text { P value }\end{array}$ \\
\hline \multirow[t]{4}{*}{ II } & Number & 19 & 19 & \\
\hline & Median & 173.6 & 172.1 & \multirow[b]{3}{*}{0.94} \\
\hline & Minimum & 112.6 & 47.62 & \\
\hline & Maximum & 2318.3 & 2294.2 & \\
\hline \multirow[t]{4}{*}{ III } & Number & 16 & 16 & \\
\hline & Median & 147.95 & 195 & \multirow{4}{*}{$0.002^{*}$} \\
\hline & Minimum & 95.45 & 123.8 & \\
\hline & Maximum & 297 & 455.2 & \\
\hline \multicolumn{2}{|c|}{ Significant p value } & $0.02 *$ & 0.23 & \\
\hline
\end{tabular}

Table.3 Association between TGF $\beta 1$ and ER, PR, CA15-3 and LDH 


\begin{tabular}{|l|c|c|c|}
\hline \multirow{2}{*}{ ER } & & \multicolumn{2}{|c|}{ TGFß1 } \\
\cline { 2 - 4 } & & before treatment & after treatment \\
\hline \multirow{2}{*}{ PR } & $\mathrm{r}$ & -0.138 & -0.182 \\
& $\mathrm{p}$ & 0.429 & 0.296 \\
\hline \multirow{2}{*}{ CA15-3 } & $\mathrm{r}$ & -0.357 & -0.16 \\
& $\mathrm{p}$ & $0.035^{*}$ & 0.359 \\
\cline { 2 - 4 } & $\mathrm{r}$ & -0.269 & -0.158 \\
\hline LDH & $\mathrm{p}$ & 0.118 & 0.365 \\
& $\mathrm{r}$ & -0.035 & 0.123 \\
\hline
\end{tabular}

r: Spearman correlation coefficient

*statistically significant

Table.4 Metastasis in breast cancer females by Cox regression

\begin{tabular}{|c|c|c|c|c|c|}
\hline \multirow[t]{2}{*}{ predictors } & \multirow[t]{2}{*}{$\boldsymbol{\beta}$} & \multirow[t]{2}{*}{$P$ value. } & \multirow{2}{*}{$\begin{array}{l}\text { Odds } \\
\text { ratio }\end{array}$} & \multicolumn{2}{|c|}{ 95.0\% CI for Odds ratio } \\
\hline & & & & Lower & Upper \\
\hline \multicolumn{6}{|l|}{ ER } \\
\hline - Negative( & & & & & \\
\hline - Positive & -2.963 & $0.016^{*}$ & 0.052 & 0.005 & 0.571 \\
\hline \multicolumn{6}{|l|}{ PR } \\
\hline - Negative( & & & & & \\
\hline - Positive & -0.744 & 0.379 & 0.475 & 0.091 & 2.493 \\
\hline \multicolumn{6}{|c|}{ TGF $\beta 1$ after treatment } \\
\hline - $<$ median & & & & & \\
\hline - >median & 1.147 & $0.018^{*}$ & 3.148 & 2.588 & 16.855 \\
\hline
\end{tabular}

(R) Reference group

* Statistically significant $(\mathrm{p}<0.05)$

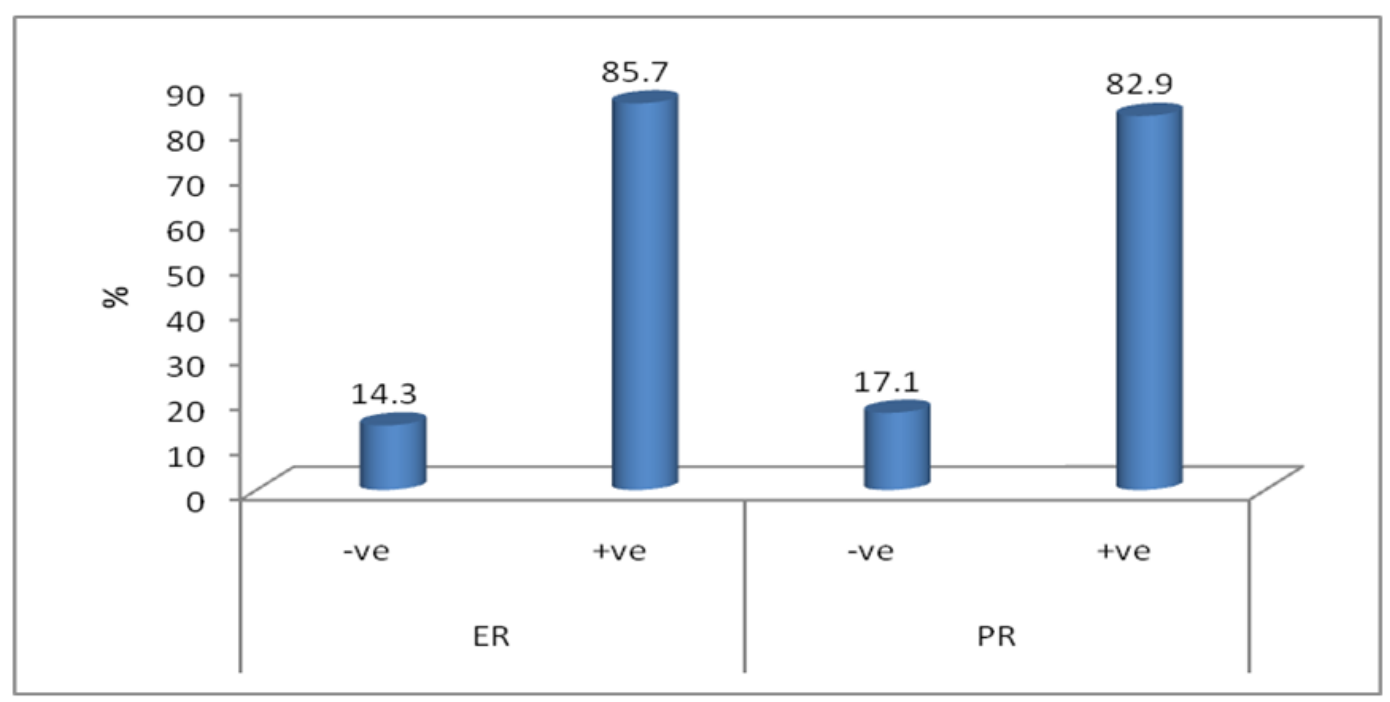

Figure.1 Estrogen receptor and progesterone receptor prevalence in breast cancer females 
De Kruijf et al., (2012) had dem onstrated that the combination of elevated TGF $\beta$ after treatment and positive biomarkers(ER and PR) can provide valuable prognostic value for breast cancer patients. Stratifying tumors according to the low or high expression of TGF $\beta$ biomarkers had strong progression free survival implications in patient population.

Also we found by binary logistic test that every increase in TGF $\beta 1$ before treatment one unit decrease progression of breast cancer, marking the role of TGF $\beta 1$ as a tumor suppressor and evidencing the existence of a TGF $\beta 1$ switch. In consistent with our study, Zarzynska, 2014 reported that cancer cells need higher TGF $\beta 1$ concentration to receive TGF $\beta 1$ anti mitotic stimulus, which reduce the risk of breast cancer progression.

Higher levels of TGF $\beta 1$ are detected among breast cancer females than the control group.

Statistically significant difference between TGF $\beta 1$ after treatment as regarding to metastasis occurrence. This indicates that circulating TGF $\beta 1$ after treatment may be used as a prognostic marker in breast cancer patients.

The present study shows that there were statistically significant predictors affecting metastasis rate among studied cases when both ER was positive and TGF $\beta 1$ after treatment was more than median.

\section{Recommendations}

Amani D, Khalilnezhad A, Ghaderi A, Niikawa N, and Yoshiura K I (2014): Transforming growth factor beta 1 (TGF$\beta 1)$ polymorphisms and breast cancer risk. Tumor Biology; 35(5): 4757-4764.

Anderson, K. N., Schwab, R. B., and Martinez, M. E (2014): Reproductive risk factors and breast cancer subtypes: a review of the literature. Breast cancer research and treatment; 144(1): 1-10.

Bierie, B., Stover, D. G., Abel, T. W., Chytil, A., Gorska, A. E., Aakre, M., and Moses, H. L (2008): Transforming growth factor$\beta$ regulates mammary carcinoma cell survival and interaction with the adjacent microenvironment. Cancer research; 68(6): 1809-1819.

Bray, F., Ferlay, J., Soerjomataram, I., Siegel, R. L., Torre, L. A., and Jemal, A. (2018): Global cancer statistics 2018: GLOBOCAN estimates of incidence and mortality worldwide for 36 cancers in 185 countries. CA: a cancer journal for clinicians; 68(6): $\quad$ 394-424.

Cancer.Net Editorial Board (2019): Breast Cancer: Stages| Cancer. Net7/2019, $<$ https://www.cancer.net > cancer-types > breast-cancer $>$ stages.

Chu, W.G. and Ryu, D.W (2016): Clinical significance of serum CA15-3 as a prognostic parameter during follow-up periods in patients with breast cancer. Annals of surgical treatment and research; 90(2): 57-63.

Ciftci, R., Tas, F., Yasasever, C.T., Aksit, E., Karabulut, S., Sen, F., Keskin, S., Kilic, L., Yildiz, İ., Bozbey, H.U. and Duranyildiz, D (2014): High serum transforming growth factor beta 1 (TGFB1) level predicts better survival in breast cancer. Tumor Biology; 35(7): 6941-6948.

Darakhshan, S., and Ghanbari, A (2013): Tranilast enhances the antitumor effects of tamoxifen on human breast cancer cells in vitro. Journal of biomedical science; 20(1): 76.

Darwish, I. A., Wani, T. A., Khalil, N. Y., and Blake, D. A (2012): Novel automated flow-based immunosensor for real -time measurement of the breast cancer biomarker CA15-3 in serum. Talanta; 97: 499-504.

Dave, H., Shah, M., Trivedi, S., and Shukla, S (2012): Prognostic utility of circulating transforming growth factor beta 1 in breast cancer patients. The International journal of biological markers; 27(1): 53- 
59.

De Kruijf, E. M., Dekker, T. J. A., Hawinkels, L. J. A. C., Putter, H., Smit, V. T. H. B. M., Kroep, J. R., and Mesker, W. E (2012): The prognostic role of TGF- $\beta$ signaling pathway in breast cancer patients. Annals of oncology; 24(2): 384390.

Ebeling, F.G., Stieber, P., Untch, M., Nagel, D., Konecny, G.E., Schmitt, U.M., FatehMoghadam, A. and Seidel, D (2002): Serum CEA and CA 15-3 as prognostic factors in primary breast cancer. British Journal of Cancer; 86(8):1217.

El-Aziz, G., Kamel, M. M., Alkaffas, M., Abdelhady, E. G., and Rashed, L. A (2018): Can Transforming Growth Factor Beta Affect Breast Cancer by Targeting MicroRNA 195. J Mol Cell Biochem ; 2(1): 1-4.

Gomes L R, Terra L F, Wailemann R A M, Labriola L and Sogayar M C (2012): TGF- $\beta 1$ modulates the homeostasis between MMPs and MMP inhibitors through p38 MAPK and ERK1/2 in highly invasive breast cancer cells.BMC Cancer; 12(1): 26.

Hachim, M.Y., Hachim, I.Y., Dai, M., Ali, S. and Lebrun, J.J (2018): Differential expression of TGF $\beta$ isoforms in breast cancer highlights different roles during breast cancer progression. Tumor Biology; 40(1):1010428317748254.

Ivanović, V., Demajo, M., Krtolica, K., Krajnović, M., Konstantinović, M., Baltić, V., Prtenjak, G., Stojiljković, B., Breberina, M., Nes, Z. and NikolićVukosavljević, D (2006):Elevated plasma TGF- $\beta 1$ levels correlate with decreased survival of metastatic breast cancer patients. Clinicachimica acta; 371(1-2): 191-193.

Jurisic, V., Radenkovic, S., and Konjevic, G (2015): The actual role of $\mathrm{LDH}$ as tumor marker, biochemical and clinical aspects. In Advances in Cancer Biomarkers (pp. 115-124). Springer, Dordrecht.

Kajdaniuk D, Marek B, Borgiel-Marek H, and
Kos-Kudła B (2013): Transforming growth factor beta1 (TGFbeta1) in physiology and pathology. EndokrynologiaPolska; 64 (5): 384-396.

Kuroda, H., Muroi, N., Hayashi, M., Harada, O., Hoshi, K., Fukuma, E., and Imai, Y (2019): Oestrogen receptornegative/progesterone receptor-positive phenotype of invasive breast carcinoma in Japan: re-evaluated using immunohistochemical staining. Breast Cancer; 26(2): 249-254.

Lee J C, Lee K M, Kim D W and Heo D S (2004): Elevated TGF- $\beta 1$ secretion and down-modulation of NKG2D underlies impaired NK cytotoxicity in cancer patients. Journal of Immunology; 172 (12): 7335-7340.

Massagué, J (2012): TGF $\beta$ signaling in context. Nature Reviews Molecular Cell Biology; 13(10): 616

Mudduwa, L.K., Wijayaratne, G.B., Peiris, H.H., Gunasekera, S.N., Abeysiriwardhana, D. and Liyanage, N (2018): Elevated pre-surgical CA153: does it predict the short-term diseasefree survival of breast cancer patients without distant metastasis?. International journal of women's health; 10: 329.

Panis C, Herrera A C, Victorino V J, Aranome A M and Cecchini R (2013): Screening of circulating TGF- $\beta$ levels and its clinicopathological significance in human breast cancer. Anticancer Research; 33 (2): 737-742.

Panjarian, S., Madzo, J., Slater, C., Jelinek, J., Chen, X. and Issa, J.P (2019): Abstract P3-05-03: Identification of epigenetically silenced breast cancer driver genes.

Parvani J G, Galliher-Beckley A J, Schiemann B J and Schiemann W P (2013): Targeted inactivation of $\beta 1$ integrin induces $\beta 3$ integrin switching, which drives breast cancer metastasis by TGF- $\beta$. Molecular Biology of the Cell; 24 (21): 3449- 3459.

Parvani J G, Taylor M A, and Schiemann W P (2011): Noncanonical TGF- $\beta$ signaling during mammary tumorigenesis. Journal 
of mammary gland biology and neoplasia; 16 (2): 127-146.

Porter P L (2009): Global trends in breast cancer incidence and mortality. SaludP'ublica de M'exico; 51: s141-s146.

Sandri, M.T., Salvatici, M., Botteri, E., Passerini, R., Zorzino, L., Rotmensz, N., Luini, A., Mauro, C., Bagnardi, V., Cassatella, M.C. and Bottari, F (2012):Prognostic role of CA15. 3 in 7942 patients with operable breast cancer. Breast cancer research and treatment; 132(1):317-326.

Scherer, S.D., Bauer, J., Schmaus, A., Neumaier, C., Herskind, C., Veldwijk, M.R., Wenz, F. and Sleeman, J.P (2016): TGF- $\beta 1$ is present at high levels in wound fluid from breast Cancer patients immediately post-surgery, and is not increased by intraoperative radiation therapy (IORT). PloS one;11(9): e0162221.

Segen's Medical Dictionary (2012): Allred scoring system - Medical Dictionary The Free Dictionary, <https://medical dictionary.thefreedictionary.com $>$ Allred + scoring+system.

Sheen Y Y, Kim M J, Park S A and Nam J S (2013): Targeting the transforming growth factor- $\beta$ signaling in cancer therapy. Biomolecules and therapeutics; $21(5): 323$.

Shushan Shweta J, Kusuma V and Geethamani V (2013): Immunohistochemistry for ER/PR and HER2/neu in breast carcinomas - Their interrelationship and association with histopathological grading and clinical parameters. Int J Med Appl
Sci; 2: 10719.

Surakasula, A., Nagarjunapu, G.C. and Raghavaiah, K.V (2014):A comparative study of pre-and post-menopausal breast cancer: Risk factors, presentation, characteristics and management. Journal of research in pharmacy practice; 3(1):12.

Teama, S., Fawzy, A., Teama, S., Helal, A., Diyaa, A., Drwish, T. E., and Desouky, E (2016): Increased Serum Endoglin and Transforming Growth Factor $\beta 1$ mRNA Expression and Risk of Hepatocellular Carcinoma in Cirrhotic Egyptian Patients. Asian Pacific Journal of Cancer Prevention; 17(5): 2429-2434.

Tripsianis, G., Papadopoulou, E., Romanidis, K., Katotomichelakis, M., Anagnostopoulos, K., Kontomanolis, E., Botaitis, S., Tentes, I. and Kortsaris, A (2013):Overall survival and clinicopathological characteristics of patients with breast cancer in relation to the expression pattern of HER-2, IL-6, TNF- $\alpha$ and TGF- $\beta 1$. Asian Pacific Journal of Cancer Prevention; 14(11):6813-6820.

Wakefield, L. M., Letterio, J. J., Chen, T., Danielpour, D., Allison, R. S., Pai, L. H., and O'Shaughnessy, J. A (1995): Transforming growth factor-beta1 circulates in normal human plasma and is unchanged in advanced metastatic breast cancer. Clinical cancer research ; 1(1): 129-136.

Zarzynska, J. M (2014): Two faces of TGF beta1 in breast cancer. Mediators of inflammation, 2014.

\section{How to cite this article:}

Amr Mohamed El-Sabbagh, Wafaa Saad Zaghloul, Raghda El-sayed Megahed and Nazem Mohammed Shams. 2020. Transforming Growth Factor Beta 1 (TGF $\beta 1$ ) as an Immunological Marker in Breast Cancer Patients. Int.J.Curr.Microbiol.App.Sci. 9(04): 1344-1355. doi: https://doi.org/10.20546/ijcmas.2020.904.160 